LJUBICA PERINIĆ

Department of Archaeology

Institute for Historical and Social Sciences

Croatian Academy of Sciences and Arts

Zagreb, Croatia

bperinic@gmail.com

LJUBIŠA VASILJEVIĆ

National Museum Kruševac

Kruševac, Serbia

1jubisa05@gmail.com
Received: November $2^{\text {th }} 2021$

Accepted: November $20^{\text {th }} 2021$

Original research article

904:255.6"652"(497.11)

904:73.046"652"(37)

COBISS.SR-ID 55403529

https://doi.org/10.18485/arhe_apn.2021.17.6

\title{
ICONOGRAPHIC REPRESENTATIONS OF ANTHROPOTHERIOMORPHIC SILVANUS IN THE TERRITORY OF SERBIA (EASTERN PROVINCE OF DALMATIA)
}

\begin{abstract}
Representations of the god Silvanus most commonly depict two iconographically different deities. One is shown in the anthropomorphic form, the other in the form in which most scientists usually recognise the Greek god Pan, meaning that the deity was shown in an anthropotheriomorphic form, that is to say, with horns and goat legs. In this paper, votive monuments are examined that have been discovered in the territory of today's Serbia on which Silvanus was depicted in an anthropotheriomorphic form. These are findings from Zemun, Prijepolje, an unknown site in western Serbia, Jabučje near Lazarevac and Gradašnica near Leskovac.
\end{abstract}

KEYWORDS: SILVANUS, SERBIA, FINDINGS, ANTHROPOTHERIOMORPHIC REPRESENTATION.

Representations of the god Silvanus most commonly depict two iconographically different deities. ${ }^{1}$ One is shown in the anthropomorphic form, and in the other form many usually recognise the Greek god Pan, meaning that the deity was depicted in an anthropotheriomorphic form, that is to say, with horns and goat legs. In this paper, we will examine votive monuments found in the territory of today's Serbia on which Silvanus was depicted anthropotheriomorphically.

From the area of Pannonia (Zemun), we have the finding of a fragmented relief-epigraphic

1 This article is a result of research activities performed within the research project "Among Gods and Men / The Cults and the Population of Roman Dalmatia According to the Votive Inscriptions", financed by the Croatian Science Foundation "Among Gods and Men" (HRZZ IP-2020-027214, headed by Ljubica Perinić). monument, on which, along with a representation of Liber, there is a smaller, damaged figure of Silvanus with goat legs (the head and upper part of the body are missing), and Silvanus is placed next to a female figure. The monument most probably originates from a sanctuary of Dionysus.

From the eastern part of the province of Dalmatia, today's western Serbia, we have a relief-epigraphic monument from Prijepolje and a relief monument from an unknown site, which is kept at the Museum of Užice. We will also include here the finding of a silver cup from Jabučje, near Lazarevac, where, within the rich relief decoration, there is also a representation of Pan leading a goat to the altar. It can be assumed that these monuments, for the most part, can be linked to the Del- 
matean type of representations of Silvanus, typical for the inner parts of the province of Dalmatia.

A unique finding from Moesia is an iron ring with a silver gem from Gradašnica, near Leskovac. There is a representation of Silvanus, playing with a billy goat, on the gem. The question remains as to whether the ring had a votive character, as seems to be the case with the findings discovered in the north of Pannonia.

The research of the cult of Silvanus in these areas can be divided into two phases and two main streams: one denies any autochthonous character to Silvanus, considering him to be an Italic deity, and the other believes that Silvanus, at least in terms of the province of Dalmatia, was a response of the local population to the Roman influence, that is to say, the syncretism of a local deity with the Italic Silvanus. As already mentioned, we will examine three votive monuments linked to the cult of Silvanus in this paper, along with two everyday use items (a cup and a ring). All three votive monuments depict the so-called Dalmatian type of Silvanus, while only one of the two everyday use items could possibly be linked to Silvanus. The votive monument from Zemun can be linked to the syncretism of Silvanus and Liber, which can be linked to, or represents a continuation of, the theory of a notable identification of Silvanus and Liber in the area of today's Bosnia and Herzegovina, i.e. the eastern part of the province of Dalmatia.

The spread of the Roman religion was a part of the same principle used in politics as well, which also intertwined in this system. Therefore, it could be (justly) assumed that such a system of the Roman Empire, which was a novelty in the area of Dalmatia, had to have had an influence on the religion of conquered and assimilated autochthonous ethnic groups: if not by force, then with the passing of time and by living together.

What changes were those? Was this influence felt on the autochthonous religious system or on beliefs themselves? What was the religious system of the population of Dalmatia before it became a part of the Roman Empire? What was the nature of the autochthonous religious system? These questions will be more easily answered if our perception of autochthonous communities is supported by knowledge of their social structures, organisation and administration, religion and all other elements that form everyday life. As for Dalmatia, we know of some of the local deities, but not much about the religious system as a whole, and certainly not as well as we know the Roman pantheon and its gods.

The most popular gods (if not supreme) in the province of Dalmatia differ by ethnic community. According to findings, Liburnians (settled along the coastal area of the north-eastern Adriatic Sea, between the rivers Arsia - Raša and Titius - Krka) worshiped local goddesses with different names, e.g. Ica, Ansotica and Sentona. The situation with the Iapodes (settled to the north from mount Velebit, to the north and more in the hinterland than the Liburnians) was not as clear, but it is probable that Bindus, who was assimilated with Neptune, was the supreme, or at least the most popular, deity; for the Delmatae (eastern Adriatic coast, between the rivers Krka and Neretva in Croatia and the hinterland, today in Bosnia and Herzegovina), the supreme deities were Silvanus and Diana.

Often, only the name of the deity is preserved on inscriptions, hence, it can be difficult to unfold their true nature and the scope of their influence. Sometimes, an epichoric deity could have been worshiped through several religions within an ethnically more uniform area or it could have been worshiped in a geographically wider context. Also, it cannot be excluded that a seemingly Roman deity, e.g. by his name, could have been hiding an autochthonous deity. Judging by the number of preserved reliefs and inscriptions dedicated to Silvanus, his cult was very widely spread among the inhabitants of Dalmatia. However, whether a Delmatean deity was hiding under the guise of Silvanus, there is still no final answer, nor is there irrefutable arguments on the topic. To date, the name of a possible autochthonous deity whose traits could have been recognised in Silvanus by 
the autochthonous population has yet to be found. In the research of the cult of Silvanus, finding the name of the unknown deity would be a huge, if not the final, step forward in solving this question.

Solving the mentioned unknown facts linked to these monuments would contribute to a deeper understanding of the relationships between the autochthonous population and the Roman imperial culture. As for the two phases and two main streams in the research of the cult of Silvanus, we will mention only some of the authors who are (or were) dedicating special attention to this topic. Older foreign and local scientists, e.g. A. von Domaszewski (Domaszewski 1895: 1-123), R. Schneider (Hirschfeld and Schneider 1885: 31-84) and D. Rendić-Miočević (Rendić-Miočević, D. 1989: 461-507) believed that a true interpretatio Romana occurred in Dalmatia, i.e. that under the Latin name of Silvanus a (supreme) autochthonous deity was worshiped, whose name, unfortunately, was not preserved to today. The same belief is also shared by N. Cambi (Cambi 1968: 131-141).

In more recent scientific literature, there are two streams. One is represented by P. Dorcey, who negates any autochthonous trait to the Delmatean Silvanus. Furthermore, his opinion is that the Delmatean Silvanus was, in fact, the Greek Pan (Dorcey 1992: 49-84). The other stream is represented by A. M. Nagy, who does attribute some autochthonous traits to the Dalmatian/Delmatean Silvanus (Nagy 1994: 773).

As for the scientists from this region, for example D. Maršić (Maršić 1997-1998: 45-69), A. Rendić-Miočević and N. Cambi, they still believe that Silvanus was a local deity. A. Rendić-Miočević analysed this problem in detail, and he came to the conclusion that Silvanus was an autochthonous deity, who attained his visual aspect of Pan through the process of interpretatio Graeca, and then, through interpretatio Romana, attained the name of the Italic deity (Rendić-Miočević, A. 1982: 121-140). His approach is shared by some other scientists as well (Matijašić and Tassaux 2000: 89).

Representations of Silvanus in Dalmatia differ from those in Italy, and it was believed that there were even differences between variations depending on different geographical areas in Dalmatia. It was believed that along the Dalmatian coast, i.e. in the area that was longest and most intensely under the Greek influence, Silvanus was most commonly represented alone and in the form of Pan. The Aegipan Silvanus usually has a mild facial expression, stands en face and is surrounded by trees that were dedicated to him (spruce, laurel), animals (dogs, goats), as well as other symbols and attributes (cloak, pedum, syrinx, etc.). Unlike the Aegipan Silvanus, in the hinterland of the province, behind the Dinara (originally a Delmatae area), Silvanus was most commonly depicted as young and beardless, in free space, most commonly in an anthropotheriomorphic form, but also sometimes in a completely human form, which then brings him closer to the Italic Silvanus (Rendić-Miočević, D. 1989: 469).

Today, however, the catalogue of relief monuments of Silvanus was supplemented with new findings, the already mentioned differences pale and the "border" between the two areas is not so clear anymore. The monuments on which Silvanus was depicted alone still prevail in the coastal area, but the difference between the "old" and the "young" Silvanus is not notable anymore, nor is the former premise that he was depicted in free space in the hinterland (Perinić 2016: 16-20).

Three monuments dedicated to Silvanus (with nymphs) were discovered in Hvar (Ibid.: 19). On the neighbouring island of Brač, two indirect confirmations of the cult have been discovered, along with one relief, probably linked to the sanctuary of Silvanus (Demicheli: 175-185).

M. Zaninović believes that the mentioned monuments from Hvar confirm the cult syncretism of Silvanus and Liber, hence, that they connect, in a manner, the islands and the coastal Delmatae area within a unique cult image of Silvanus (Paškvalin 1963: 131; Zaninović 1966: 15-25).

The pantheon of mid-Dalmatian islands (Brač, Hvar, Vis, Korčula) is somewhat more complex 
because of the interdependence between older and more recent, durable and manifold, and cultural and ethnic influences. The Hellenistic component is represented by Zeus, Aphrodite, Artemis and Hermes; the Roman by Jupiter and Diana, while the oriental one can be recognised through Mithras. The local, autochthonous component seems to have been lost. It is not possible to determine to what extent the local population could also have seen certain traits of local deities in these components - if at all - but it was certainly possible to look for them in simple reliefs of Silvanus and Liver, whose worshipers could have been found among the local population (Ibid.: 20-21).

The worshiping of Silvanus and Liber had common elements, as was indicated on some monuments, especially on the monument from Krakašica, and especially on monuments on which Silvanus was depicted with grapes. Liber, the deity who was the protector of the vine and viniculture, one of the oldest paleo-Italic deities, was the god of fertility and vegetation in his original interpretation. Some authors believe that Liber (only in the area of today's Bosnia and Herzegovina, i.e. the eastern Roman province of Dalmatia) was identified with Silvanus. A similar opinion was held for the monuments dedicated to Liber from Užice (Зотовић 1995: 5-9).

Numerous reliefs bear witness to the approaching of Dalmatian Silvanus to Priapus, Liber, Mercury, Italic Silvanus and other deities. Liber is depicted with a (living) panther. In Gaul, where Succelus was identified with Silvanus (on several levels), the appearance of the dog or the wolf on a monument was interpreted as an expression of life in the wilderness, as opposed to the urban life. Toulec believes that an animal hide, when worn as a cloak, belongs to the sphere of Hercules' symbols, as suggested by representations of differences between rural and urban life (Toulec 1996: 47).

D. Rendić-Miočević came to the same conclusion many years before when he suggested that elements from Hercules' iconography can be identified, and not the influence of Liber, on the relief from Solin representing Silvanus, holding a lion's skin in his left, lowered hand. On that same relief, many elements can be seen united - symbols and attributes of different deities and various cults, indicating the undeniable intrusion of various elements of autochthonous religious traits, but also cult elements from Greece or Rome (RendićMiočević, D. 1989: 461-507).

Our monument from Zemun shows the extraordinary closeness of Silvanus and Liber (No. 5), considering the fact that both deities are depicted. As for the monuments marked with numbers 1 and 2, they completely correspond to the image of Silvanus that was common in the province of Dalmatia.

We will also mention that two votive monuments with inscriptions dedicated to Liber also originate from Užice. According to the testimony of Pandora Bećarević, a teacher at the Gymnasium of Užice, they were discovered in the field of Pašinovac (property of Raca Dedević), located near Užice. The first altar was made of limestone. Two dimensions of the monuments are known: the height of $100 \mathrm{~cm}$ and width of $50 \mathrm{~cm}$. A representation of a rosette can be discerned on the capital.

The text of the inscription is: $\mathrm{Lib}$ (ero) $\mathrm{P}$ (atri) $\mathrm{C}($ ) | T. Aur(elius) Ni | grinus | sac(rum) p(ro) p(atre).

The other altar from Užice was made from bluish marble. The dimensions of the altar: height $100 \mathrm{~cm}$, width $46 \mathrm{~cm}$. At the corners of the upper part of the monuments there are acroteria. N. Vulić notes that a representation of a bucranion was in the middle of the upper part of the monument. Today, this ornament cannot be seen. The text of the inscription on the other monument is:

$\mathrm{L}$ (ibero) $\mathrm{P}$ (atri) Cap() $\mid$ T. Aur(elius) Pro | vincialis $\mid$ ob honor(em) | II viratus $\mid$ v(otum) s(olvit) 1(ibens) m(erito)

For the topic of this paper, it is important to note the assumption, made by R. Zotović, that the name of Liber hides the interpretatio Roma$n a$ of the local deity of fertility, pastures, forests and meadows, who was more linked to the cult of Silvanus. The mentioned assumption was based, 
first and foremost, on the theoretical approach, that is to say, the linking of attribute compositions of Silvanus with similar ones that had to have belonged to the supreme deity of the local population, which were mostly shepherds and farmers (Вулић 1948: 248, бр, 486, 487; Зотовић 1995: 7-8; Eadem 1996/1997: 7-10).

\section{MONUMENTS CATALOGUE}

\section{PRIJEPOLJE}

Figure 1 Relief-epigraphic monument from Prijepolje, according to: Зотовић 2001: 185, сл. 5. Dating: middle of the $2^{\text {nd }}$ century ( $3^{\text {rd }}$ century?) References: CIL III 8306; Kubitschek 1928: 37 38, fig. 2; Mirković 1975: 105; Зотовић 2001: 185-186, 190; Васиљевић 2008: 50-51; Perinić 2016: 84, бр. 49.

A votive monument with a relief and inscription dedicated to Silvanus. Dimensions of the monument are: height $50 \mathrm{~cm}$, width $35 \mathrm{~cm}$. Silvanus is depicted in an anthropotheriomorphic manner, naked. He is holding a pedum in his left hand, and a syrinx in his right, semi-extended hand. From the short stylised hair (the goal was probably to depict curly hair), two goat horns are emerging, and he has only a beard, but no moustache, on his face. His legs are also those of a goat, and the hair in the upper part (on the thighs) is shown in parallel geometric zigzag lines.

The text of the inscription is:

S(ilvano) A(u)g(usto) | Mercurius | argenti | actor v(otum) 1(ibens) p(osuit)

The first row of the inscription is at the top of the relief, above the head of Silvanus. The second, third and fourth rows were written in the lower half of the relief, above the profiled place on which Silvanus is standing. The inscription is divided into two parts by the representation of the deity itself.

R. Zotović believes that the dedicant of the

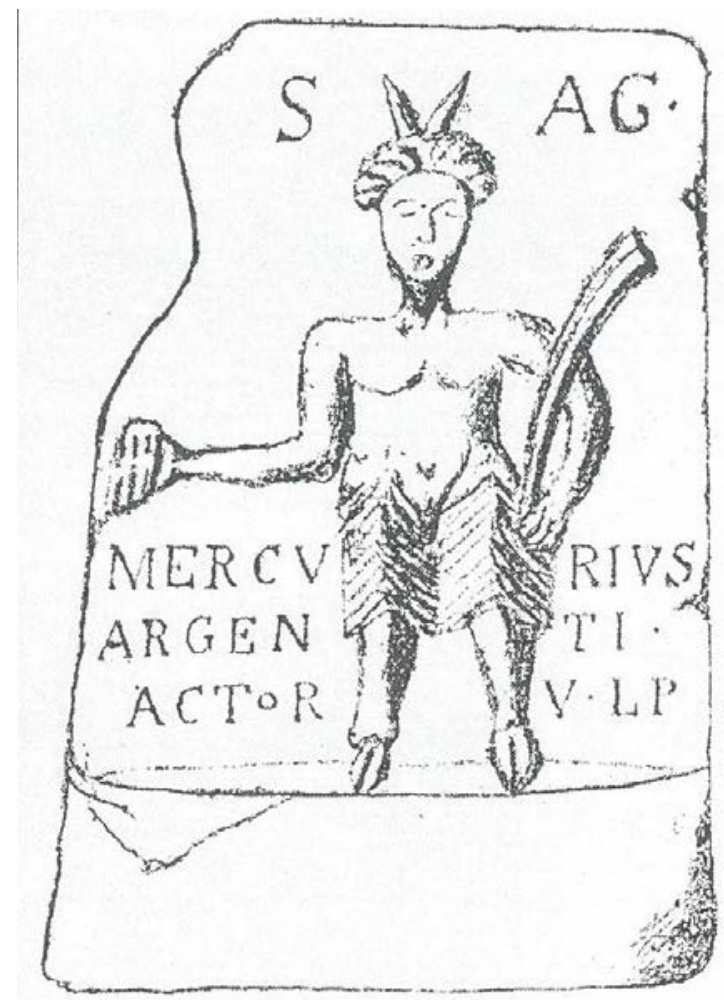

Fig. 1 Relief-epigraphic monument from Prijepolje (after: Zotović 2001: 185, fig. 5).

monument, Mercurius, was a farmer and cattle breeder who expressed his respects to Silvanus, as the protector of herds and shepherds, in order to obtain protection for his cattle, and she dates the monument into the 3rd century (Зотовић 2001: 186). M. Mirković, on the other hand, states the opinion that the inscription is linked to the silver mines, the exploitation of which in the Antiquity period is registered in the surroundings of Kolovrat and Prijepolje (Mirković 1975: 105, nap. 42).

Certainly, the opinion of M. Mirković is closer to the truth, considering the fact that Mercurius introduced himself on this votive monument with his full title: argenti actor. During the reign of Marcus Aurelius, all Illyrian mines were united, and the silver mines from the south-east of Dalmatia were managed from the Roman settlement in Kolovrat, near Prijepolje, in the Lim valley, where our senior mining clerk Mercurius comes from.

Clerks with the title of actors and procuratores managed large agricultural units (Škegro: 1998, 95-96), especially during the Late Antiquity pe- 


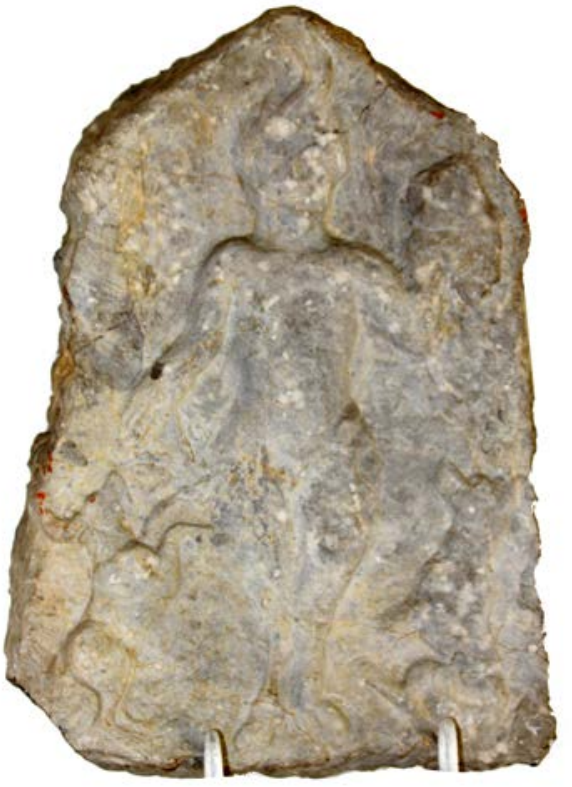

Fig. 2 Relief monument from an unknown site in western Serbia (photo: Documentation of the National Museum of Užice).

riod (Sanader 1995: 101). Near the end of the first half of the 2nd century, imperial overseers of silver mines with provincial designations appeared. Unlike the overseers of mining regions in the Lim valley, in the south-east of Dalmatia and Kosmaj, who were imperial freedmen, the overseers of Pannonian silver mines came from the rank of Roman knights. Aside from the aforementioned Mercurius, a senior mining clerk, lower-rank clerks have also been registered in this area, and those were all trustworthy persons, considering the fact that they all came from the so-called Familae Caesaris (Mirković 1975: 106). A. Mirković dated the monument into the period before the reform of Marcus Aurelius (Škegro 1998: 96).

\section{UNKNOWN SITE, WESTERN SERBIA}

Figure 2 Relief monument from an unknown site in Western Serbia, photo: Documentation of the National Museum Užice ${ }^{2}$

2 We would like to thank our colleague Marina Kotarac for her cooperation and for allowing us to use the photo from the collection of the National Museum Užice.

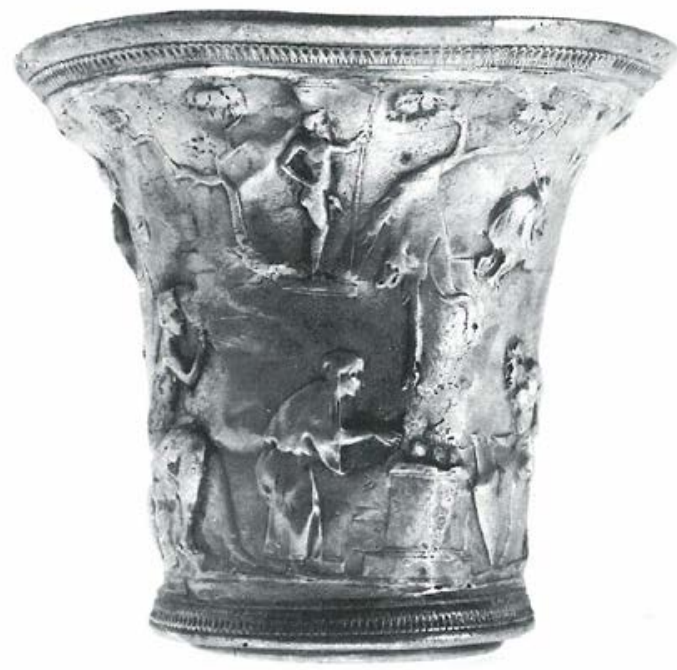

Fig. 3 Silver cup from Jabučje (after: Popović 1994: 255, cat. 140).

Dating: $3^{\text {rd }}$ century

References: Zotović 1992/1993: 177-182, fig. 1; Васиљевић 2008: 57-59; Perinić 2016: 50.

The second relief representation of Silvanus, also made of stone, was found on a monument from the collection of the National Museum Užice. The exact find location is unknown.

The relief was carved on a rectangular stone plate, shaped into a triangular ending in the upper part. The surface of the relief was relatively well preserved. It was partially damaged on the bottom edge, on both the left and the right side. Climatic conditions caused damage to the head, more precisely, the hair, both hands and the left side of the upper part of the body. The plate is $40 \mathrm{~cm}$ long, 30 $\mathrm{cm}$ wide and $10 \mathrm{~cm}$ thick.

Silvanus is depicted in a standing position, en face, as a bearded, naked man with goat legs and horns (anthropotheriomorphically). Hairy parts can be noted on the legs. The depicted horns are exceptionally graceful, but also uncommon. They are growing in parallel, from the centre of the head, bending slightly to the right. On the basis 
of the well preserved upper right part of the head, it can be concluded that hair was carved in almost parallel incisions, imitating curvy or wavy hair, the same as on the previous monument. The short beard is carved in, giving the impression of being thick and wavy. There is a nipple preserved on the right side of the breasts.

Silvanus is (most probably) holding a syrinx in his left hand. This arm is bent and raised. The pipes of the syrinx are unrecognisable now. In his right, relaxed hand, there is an object, which could be a grape cluster, but we cannot be certain of it because the relief is very much damaged in this part. A goat, or perhaps a dog, is depicted on the left side of the monument (another dog is undoubtedly shown on the other side of the deity), raised on its hind legs towards the grapes(?) and leaning on Silvanus' thigh with its front legs. A pedum(?), barely visible, in the form of a thin line, is in the right hand of the deity. It can be seen that the animal (dog or goat) is grabbing with its mouth the item, whatever it may be, that Silvanus is holding in his lowered hand. The indisputable representation of a dog is on the right side of the relief, also near Silvanus' legs. The dog, shown with its head raised, is looking towards the deity. The background of the relief is decorated in the same manner as the hairy parts of Silvanus' legs.

\section{JABUČJE NEAR LAZAREVAC}

Figure 3 Silver cup from Jabučje, according to: Поповић 1994: 255, кат. 140

Dating: first half of the $1^{\text {st }}$ century AD.

References: Величковић 1983: 61-62, бр 35; Поповић 1994: 45-54, 255, бр. 140; Васиљевић 2008: 66-68.

Silver cup made in the casting and embossing technique. It was found during sand extraction from the Kolubara, in the place called Jabučje, near Lazarevac. It represents a part of a luxurious set of silver vessels. It is dated into the first half of the 1st century. The dimensions of the cup are: diameter $12.3-13.2 \mathrm{~cm}$, height $11.2 \mathrm{~cm}$. The weight of the cup is 341.85 grams. Today, it is kept at the National Museum in Belgrade (inv. no. 4102/III).

The cup (calathus) is funnel shaped, gradually widening from the bottom to the opening. It is made of three parts: insert (recipient), with a massive ornamented rim, outer shell with a relief representation and a massive ornamented foot. The insert consists of an embossed tin recipient, with a rim decorated along the edge with two rows of impressed ornaments. The massive tin foot is decorated in the same manner. The outer shell of the cup (emblema) was embossed, from thin silver tin. It has a relief representation of a libation in a closed space, surrounded by walls. Beneath the tree (arbor sacrum), on whose branches a syrinx and goat hide are hanging, there is a plateau with an itiphallic Silenus standing on it, turned to the right, with a thyrsus in his right hand. Under the pedestal of the statue in the middle of the composition, there is an altar, on which a priestess, standing on the left side, is offering a sacrifice. Behind her, there is a semi-nude Maenad, playing a double flute. For us, the most interesting representation is located on the right side, with Pan leading a goat, which is resisting, to the altar (a scene that can be seen on monuments dedicated to Silvanus in the province of Dalmatia). An amphora is set against the altar. A panther is depicted behind the musician. There are numerous masks and amulets on the wall (Silenus, Pan, cantharos, thyrsi, garlands).

The recesses on the inner side of the outer shell are filled with a special lead alloy (plumbatum), so as to protect the relief composition from damage. This type of cup with a double wall appeared in the 1st century $\mathrm{BC}$, and they were being made at the beginning of the 1st century $\mathrm{AD}$ as well. The cup belongs to the rare known examples of this type. It was used for wine and it represented a part of a luxurious drinking set (argentum potorium). It was made according to the models of Alexandrian toreutic, most probably in a Campanian workshop. 


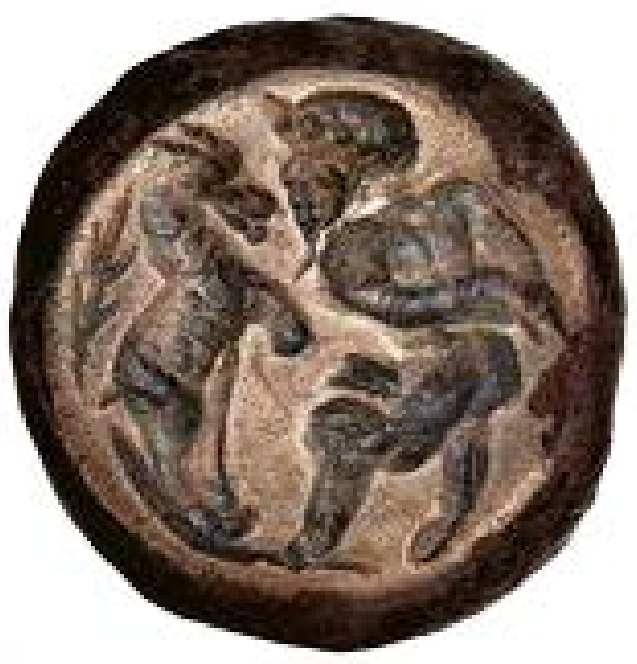

Fig. 4 Ring from Gradašnica (photo: Documentation of the National Museum Leskovac).

M. Veličković and I. Popović believed that it was Pan depicted on the cup (Величковић 1983: 62; Поповић 1994: 255). According to the attributes and other characteristics, the sacrifice scene has a Dionysian character. Since Silvanus was never a participant of a Dionysian procession and also because of the depiction of the itiphallic Silenus, which were never typical for the Italic Silvanus, and neither for the Dalmatian or Pannonian Silvanus (Perinić 2016: 81), we would agree with the surmises of M. Veličković and I. Popović.

Even though Silvanus and the father of Silenus, Pan, have traits which are similar or identical (when observing their cults in general), they still differ in most cases. In the sources, they appear together, but it is always, without exception, clear that those are two different deities. What they have in common is: lordship of the forests, nudity, company of nymphs and shepherds, and a depiction of pines. It is precisely those things that differentiate Faun (as the Roman counterpart of Pan) from Silvanus that also differentiate Pan from Silvanus: sexual aggression, musical talent and a tendency to cause panic. Those differences are visible not only in the literature, but also in the cult practice, from which two iconographically different deities originate (Perinić 2015: 86; Dorcey 1992: 16, 40).

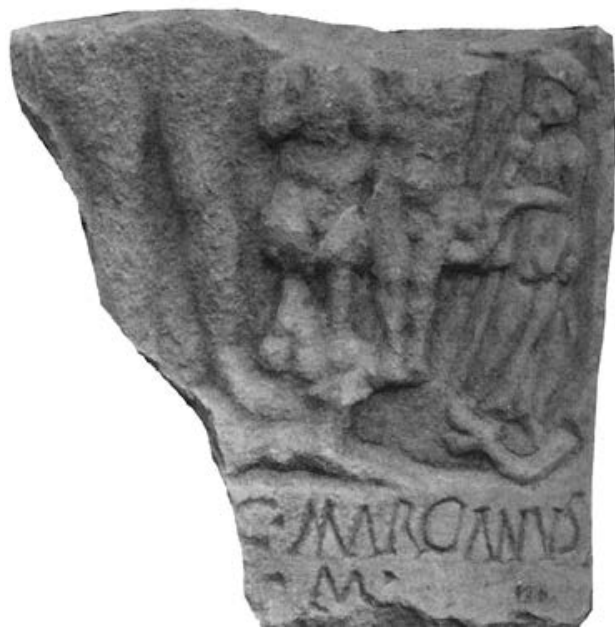

Fig. 5 Relief-epigraphic monument from Zemun (after: Dautova Ruševljan 1983: Pl. 21, fig. 3).

\section{GRADAŠNICA NEAR LESKOVAC}

Figure 4 Ring from Gradašnica, photo: Documentation of the National Museum of Leskovac ${ }^{3}$ References: Зотовић 1997: 23-27; Васиљевић 2008: 68-70.

Dating: middle of the $2^{\text {nd }}$ century - end of Antiquity

The National Museum of Leskovac has an example of an iron ring with an incrusted silver gem. It is an accidental finding, which arrived at the Museum in 1985. The finding was discovered at the site of Musin Grob, in the village of Gradašnica. The ring is preserved in a fragmented state - the head of ring with the shoulder and slightly preserved beginning of the band on one side.

The band and the head of the ring make up one whole piece. The head of the ring is round, with a diameter of $1 \mathrm{~cm}$. The shoulders of the ring, judging by the side which was preserved, had the shape of a short and rounded triangle. On the head of the ring, in a round girdle, a silver gem was set with a representation of Silvanus(?), playing with a billy goat. On the right side, there is a depiction of Sil-

3 We would like to thank our colleagues Smilja Jović, Julijana Pešić, Vladimir Stojanović and Vladimir Stevanović for their cooperation and for allowing us to use the photos from the collection of the National Museum of Leskovac. 
vanus(?) as a bearded man, with a naked upper part of the body. Silvanus(?) has the horns and legs of a billy goat. The representation of Silvanus(?) is "frozen" in a semi-turn, his head turned left, towards the billy goat, and hands outstretched to the right. He is holding an object in his hand, which is not clearly visible, but it can be assumed that it is a syrinx, which the deity is holding away from the billy goat. On the left side of the gem, a billy goat is shown, jumping. Behind the billy goat, a branch of a tree is depicted. At the very bottom, under the feet, the horizontal line of the ground is shown.

The scene was made in the casting technique, with the exception of the branch, which was engraved. The simplified production technique, casting instead of engraving, was dictated, on the one hand, by the type of material used, but only in terms of the need for a quicker, cheaper and easier production. On the other hand, the technique of casting in a mould is a testimony of the fact that artistic production was replaced by industrialisation in provincial workshops.

It can be noted on the ring that the mould from which it was made was prepared for a very good imitation of the original model, as testified by the attempt at representing the wreath and curls on the head of Silvanus(?), as well as the goat fleece or fleece on the legs. This impression is especially strengthened by the depicted horizontal line of the ground, which would have certainly been omitted in a poorer imitation. It is a similar case with the representation of the branch: here, it was probably because of the lack of space, on the one hand, and the meticulousness of details, on the other, that it was not made within the "complete" scene, in the mould, but later instead, by engraving.

The representation belongs to the group of genre scenes, which can be denoted, with all their diversity of motifs, as the group in which we find Dionysus and his dissolute companions. R. Zotović believes that it is a representation of Pan depicted on the ring (Зотовић 1997: 23-24). We believe that there is a possibility of it being Aegipan Silvanus (anthropotheriomorphic), who took on certain iconographic elements of Pan (goat legs and horns), considering the presence of the relief votive monument.

The closest analogy to our ring is a gem from the workshop Officina della Corona from Aquileia. The difference is in the fact that on the gem from Aquileia, behind the back of the billy goat, there is a representation of a tree instead of a stylisation. R. Zotović believes that it was a product of some of the earlier local workshops from the area of Moesia Superior, whose work was based on a good imitation of the original models. The workshop was probably active from the middle of the 2nd century, somewhere in the area of today's south-eastern Serbia (Ibid.: 26-27).

\section{ZEMUN (TAURUNUM)}

Figure 5 Relief-epigraphic monument from Zemun (Taurunum), according to: Dautova Ruševljan 1983: T. 21, sl. 3

References: Dautova Ruševljan 1983: 29, 89, T. 21/3; Васиљевић 2008: 55-56.

Dating: $2^{\text {nd }}$ century

A fragment of a votive monument, from white marble, with an inscription and a relief scene from the cycle of Dionysus. It was found in 1891, in Zemun (Taurunum), in the place of a probable Dionysus sanctuary. Today, it is kept at the Archaeological Museum in Zagreb (inv. no. 113). The dimensions of the preserved fragment are: height $18.5 \mathrm{~cm}$, width $18 \mathrm{~cm}$, thickness $3 \mathrm{~cm}$.

The preserved part of the inscription is:

C Marcianus | M.

On the fragment of the votive monument from Zemun (Taurunum), we can see part of a figure of Liber, in larger dimensions, and to the right of him, a smaller figure of Silvanus, with goat legs, and next to him, on the same level, a female figure, without her head. On the right side of the plaque, there is a clothed female figure, leaning on her right arm, and holding something in her left 
hand, with the left arm bent at the elbow.

There is a stylised representation of a snake under the female figure, while a panther can be discerned near the feet of Liber. The folds of clothing of this figure are vertically indicated, sharp and rough, while the other parts of the body are made in a disproportional and unskilful manner. Silvanus(?) is depicted with goat legs, playing the syrinx. The relief probably originates from the sanctuary of Dionysus in Taurunum. The existence of this sanctuary is indicated by a large number of fragments with representations of Liber and Libera, Hercules, Maenads, Silvanus et al., discovered near the foundations of a Roman building. The remains of the sanctuary and the reliefs were discovered in 1891 at the corner of Račja and Tri Goluba Streets (later Zmaj Jovina and Gajeva Street, respectively), at a depth of $2.5 \mathrm{~m}$. All find from this site were taken to Zagreb that same year.

The worship of Liber and Silvanus had elements in common, as can be noted on certain monuments discovered in Dalmatia, especially in the area settled by Delmatae (Perinić 2016: 19). Here, we should single out the monument from Karakašica, near Sinj (Ibid.: T. III/82), which is certainly comparable to the monument from Zemun.

Furthermore, for the sake of comparison, we can also mention two monuments from Salona and one from Županjac, near Tomislavgrad (Perinić 2016: Salona: T. III/1 and III/3; Županjac: T. III/44). On these monuments, Silvanus is holding a grape cluster in his hand, with which some scientists believe that it brings Silvanus into direct connection with Liber (Rendić-Miočević, 2007: 33-43; Matijević i Kurilić 2011: 154-155; Džino 2012: 265).

Furthermore, there are opinions that Silvanus was equated to Liber in the area of eastern Bosnia and Herzegovina (Paškvalin 1963: 131; Zaninović 1966: 20-21). For those reasons, we believe that there are two different levels, each of them demanding special attention, and that is the connection between Silvanus and Liber, and Liber and Dionysus, in which Silvanus and Dionysus do not meet, or maybe actually do meet, and that is a topic that re- quires especially comprehensive investigation.

We have presented, on the pages of this paper, monuments with an anthropotheriomorphic representation of the god Silvanus, originating from the area of today's Serbia. The fundamental differences linked to the symbolism of certain representations and their connection to various deities were also presented. By using the scientific knowledge available so far, we have attempted to bring forth the fundamental suppositions on the creation of this type of representation of this deity and the reasons which lead to him being worshiped, which have their specificities in the Balkan-Pannonian area, from which the presented findings originate.

\section{BIBLIOGRAPHY}

\section{Cambi, N. 1968}

Silvan - Atis, primjer kultnog sinkretizma, Diadora 4: 131-141.

Dautova Ruševljan, V. 1983

Rimska kamena plastika u jugoslovenskom delu provincije Donje Panonije, Novi Sad: Vojvođanski muzej - Savez arheoloških društava Jugoslavije.

\section{Demicheli, D. 2010}

Reljef nimfa i Silvana iz Vodne jame na otoku Braču, u: Arheološka istraživanja na srednjem Jadranu (Znanstveni skup Arheološka istraživanja na srednjem Jadranu, Vis, listopad 2009), ur. S. Ivčević. Izdanja Hrvatskog arheološkog društva 26: Zagreb: Hrvatsko arheološko društvo - Split: Arheološki muzej, 173-183.

\section{Domaszewski, A von. 1895}

Die Religion des römisches Heeres, Westdeutsche Zeitschrift für Geschichte und Kunst 14: 1-123.

\section{Dorcey, P.F. 1992}

The cult of Silvanus, A study in Roman folk religion, Leiden - New York - Köln: Brill. 


\section{Džino, D. 2012}

The cult of Silvanus: Rethinking provincial identities in Roman Dalmatia, Vjesnik za arheologiju Arheološkog muzeja u Zagrebu, treća serija, XLV: 261-278.

\section{Kubitschek, W. 1928}

Aus Dalmatien und seinem Hinterlande, Vjesnik Arheološkog muzeja u Zagrebu Vol. 15 No. 1: $35-42$.

\section{Maršić, D. 1997-1998}

Tri Silvanova žrtvenika iz Salone, Radovi Filozofskog fakulteta u Zadru 36 (23): 45-69.

\section{Matijašić, R. and Tassaux, F. 2000.}

Liber et Silvanus, Les cultes polythéistes dans l'Adriatique Romaine, in: Les cultes polythéistes dans l'Adriatique romain, eds. Ch. Delplace and F. Tassaux. Bordeaux: Ausonius Éditions, 65-119.

\section{Matijević, I. i Kurilić, A. 2011}

Dva neobjavljena žrtvenika iz Salone, Opuscula Archaeologica 35: 133-165.

\section{Mirković, M. 1975}

Iz istorije Polimlja u rimsko doba, Godišnjak Centra za balkanološka ispitivanja XIV/12: 95-108.

\section{Nagy, A. M. 1994}

Silvanus, in: Lexicon iconographicum mythologiae classica (LIMC) VII, ed. Hans Christoph Ackermann. Zürich: Artemis-Verlag, 773.

\section{Paškvalin, V. 1963}

Kultovi u antičko doba na području Bosne i Hercegovine, Glasnik Zemaljskog muzeja u Sarajevu XVIII: 127-153.

\section{Perinić, Lj. 2015}

Različite razine sinkretizma na tri Silvanova spomenika, Prilozi Instituta za arheologiju 32: 215-229.

\section{Perinić, Lj. 2016}

The Nature and Origin of the Cult of Silvanus in the Roman Provinces of Dalmatia and Pannonia, Oxford: Archaeopress.

\section{Поповић, И. 1994}

Продукција сребра у периоду раног царства: локални производи и импорт, у: Античко сребро у Србији, ур. И. Поповић, Београд: Народни музеј, 45-54.

(Popović, I. 1994

Produkcija srebra u periodu ranog carstva: lokalni proizvodi i import, u: Antičko srebro u Srbiji, ur. I. Popović, Beograd: Narodni muzej, 45-54.)

\section{Rendić-Miočević, D. 1989}

Iliri i antički svijet, Split: Književni krug.

\section{Rendić-Miočević, A. 1982}

Uz dva Silvanova svetišta u okolici Salone, Arheološki radovi i rasprave 8-9: 121-140.

\section{Rendić-Miočević, A. 2007}

Sylvanus of the Delmatae and traces of cult syncretism with Liber, Histria Antiqua 15: 33-43.

\section{Sanader, M. 1995}

Vilicus - prilog poznavanju djelatnosti upravitelja imanja i državnog namještenika, Opuscula Archaeologica 19: 97-109.

\section{Schneider, R. 1885}

Über die bildlichen Denkmäler Dalmatiens, Bericht über eine Reise in Dalmatien Bericht über eine Reise in Dalmatien, I, Arch-epigr. Mittheilungen aus Österreich-Ungarn Band IX: 31-84.

\section{Škegro, A. 1998}

Eksploatacija srebra na području rimskih provincija Dalmacije i Panonije, Opuscula archaeologica Vol. 22 No. 1: 89-117. 


\section{Toulec, D. 1996}

Images de Silvanus dans l'Occident romain, Images romaines, in: Images romaines : Actes de la table ronde organisée à l'Ecole normale supérieure, 24-26 octobre 1996, Clara Auvray-Assayas (ed.), par Florence Dupont et Clara Auvray-Assayas, Rue d'Ulm: Paris, 1996, 37-61.

\section{Васиљевић, Љ. 2008}

Култ бога Силвана и његове култне заједнице у римским провинцијама на територији Србије, Магистарски рад, Филозофски факултет, Универзитет у Београду.

(Vasiljević, Lj. 2008

Kult boga Silvana i njegove kultne zajednice u rimskim provincijama na teritoriji Srbije, Magistarski rad, Filozofski fakultet, Univerzitet u Beogradu).

\section{Величковић, М. 1983}

Антика, у: Археолошко благо Србије из музејских збирки, ур. Ј. Јевтовић, Београд: Народни музеј, 59-103.

(Veličković, M. 1983

Antika, u: Arheološko blago Srbije iz muzejskih zbirki, (ur.) J. Jevtović, Beograd: Narodni muzej, 59-103).

\section{Вулић, Н. 1941-1948}

Антички споменици наше земље, Споменик Српске академије наука XCVIII: 1-255.

(Vulić, N. 1941-1948

Antički spomenici naše zemlje, Spomenik Srpske akademije nauka XCVIII: 1-255).

\section{Zaninović, M. 1966}

Tri antička reljefa s Hvara, Opuscula Archaeologica VI: 15-25.

\section{Zotović, R. 1992/1993}

A Relief of Silvan and Some aspect of His Cult, Starinar XLIII-XLIV: 177-182.

\section{Зотовић, Р. 1995}

Антички култови на подручју Ужица, Ужички зборник 24: 5-10.

(Zotović, R. 1995

Antički kultovi na području Užica, Užički zbornik 24: 5-10).

\section{Зотовић, Р. 1996/1997}

Питања и проблеми археолошког истраживања урбанизације римског периода на подручју ужичког краја, Ужички зборник 25-26: 5-16.

(Zotović, R. 1996/1997

Pitanja i problemi arheološkog istraživanja urbanizacije rimskog perioda na području užičkog kraja, Užički zbornik 25-26: 5-16).

\section{Зотовић, Р. 1997}

Прстен са представом Пана из збирке Народног музеја у Лесковцу, Лесковачки зборник XXXVIII: 23-27.

(Zotović, R. 1997

Prsten sa predstavom Pana iz zbirke Narodnog muzeja u Leskovcu, Leskovački zbornik XXXVIII: 23-27).

\section{Зотовић, Р. 2001}

Антички култови на подручју Пријепоља и Пљеваља, y: Vestigatio Vetustatis Александрини Цермановић Кузмановић од пријатеља, сарадника и ученика, (ур.) М. Лазић, Центар за археолошка истраживања књига 20: Београд: Универзитет у Београду Филозофски факултет, 181-195.

\section{(Zotović, R. 2001}

Antički kultovi na području Prijepolja i Pljevalja, u: Vestigatio Vetustatis Aleksandrini Cermanović Kuzmanović od prijatelja, saradnika i učenika, (ur.) M. Lazić, Centar za arheološka istraživanja knjiga 20: Beograd: Univerzitet u Beogradu Filozofski fakultet, 181-195). 


\section{REZIME}

IKONOGRAFSKE PREDSTAVE ANTROPOTERIOMORFNOG SILVANA NA PROSTORU SRBIJE (ISTOČNE PROVINCIJE DALMACIJE)

KLJUČNE REČI: SILVAN, SRBIJA, NALAZI, ANTROPOTERIOMORFNA PREDSTAVA.

Predstave boga Silvana najčešće prikazuju dva ikonografski različita božanstva. Jedno je prikazano $\mathrm{u}$ antropomorfnoj formi, a drugo $\mathrm{u}$ formi u kojoj mnogi najčešće vide grčkog boga Pana, što znači da je božanstvo bilo prikazano kao antropoteriomorfno, dakle s rogovima i kozjim nogama.

U ovom radu obrađeni su votivni spomenici pronađeni na teritoriji današnje Srbije, a na kojima je Silvan prikazan antropoteriomorfno.

Sa prostora Panonije (Zemun) imamo nalaz fragmentovanog reljefno-epigrafskog spomenika na kome je na kojem se, uz predstavu Libera, nalazi manja oštećena figura Silvana sa kozjim nogama (nedostaje glava i gornji deo teverovatnije, potiče iz Dionisovog svetilišta), a Silvan je smešten pored ženske figure. Spomenik, najverovatnije, potiče iz Dionisovog svetilišta.

Iz istočnog dela provincije Dalmacije, današnje Zapadne Srbije, potiču reljefno-epigrafski spomenik iz Prijepolja i reljefni spomenik sa nepoznatog lokaliteta, koji se čuva u Muzeju u Užicu. Ovde dodajemo i nalaz srebrnog pehara iz Jabučja kod Lazarevca gde se, u okviru bogate reljefne dekoracije, nalazi i predstava Silvana koji privodi kozu žrtveniku. Može se pretpostaviti da se ovi spomenici, u najvećoj meri, mogu povezati sa delmatskim tipom predstava Silvana, karakterističnim za unutrašnjost provincije Dalmacije.

Jedinstven nalaz iz Mezije predstavlja gvozdeni prsten sa srebrnom gemom iz Gradašnice kod Leskovca. Na gemi se nalazi predstava Silvana u igri sa jarcem. Pitanje je je li prsten votivnog karaktera, kakvim se mogu smatrati oni pronađeni na severu Panonije.
Arheologija i prirodne nauke (Archaeology and Science) is an Open Access Journal. All articles can be downloaded free of charge and used in accordance with the licence Creative Commons - Attribution-NonCommercial-NoDerivs 3.0 Serbia (https://creativecommons.org/licenses/bync-nd/3.0/rs/.

Časopis Arheologija i prirodne nauke je dostupan u režimu otvorenog pristupa. Članci objavljeni u časopisu mogu se besplatno preuzeti sa sajta $i$ koristiti u skladu sa licencom Creative Commons - Autorstvo-Nekomercijalno-Bez prerada 3.0 Srbija (https://creativecommons.org/licenses/bync-nd/3.0/rs/. 